\title{
Transition to biodegradable composites as a method for solving environmental problems
}

\author{
Gulnaz Sabirova ${ }^{1}$, Ruslan Safin ${ }^{1}$, Shamil Mukhametzyanov ${ }^{1,2}{ }^{*}$ and Nour Galyavetdinov ${ }^{1}$ \\ ${ }^{1}$ Kazan National Research Technological University, Russia \\ ${ }^{2}$ National Technology Initiative Center for Advanced Manufacturing Technologies based on the \\ Institute of Advanced Manufacturing Technologies of Peter the Great St. Petersburg Polytechnic \\ University Polytechnicheskaya, 29, St.Petersburg, 195251, Russia
}

\begin{abstract}
In environmental matters, one of the most pressing problems is the efficient disposal of polymeric materials that have a negative impact on the ecology of soils and oceans. A necessary condition for the sustainable development of industrial production and processing of polymer products is the transition to polymer materials based on renewable plant raw materials, in particular polylactides, polyhydroalkanates, etc. However, the technology for the production of these types of polymers is seriously inferior to synthetic polymers in the field of energy engineering. In this regard, research in the field of creating composite materials by introducing wood filler is currently particularly relevant. This research covers the results of stress-strain behavior of wood filled polylactic wood powder composite materials thermally modified by high temperatures ranged from 200 to $240{ }^{\circ} \mathrm{C}$. Wood impact strength dependence is defined and static bending and composite density dependence on wood filler quantity and the temperature of its thermal modification is also established. It was specified that with the increasing of filler densification and its thermal treatment, the wood impact strength and composite density is decreasing, while with the reduced content of binding, the thermal modification of $200{ }^{\circ} \mathrm{C}$ has a positive impact on bending elastic coefficient. The conducted research allows identifying rational areas of use of composite materials as an effective factor in managing natural resources.
\end{abstract}

\section{Introduction}

With increasing environmental awareness and ecological risk in modern society, the human environmental degradation problem has gained more research attention. This problem is global and it is caused by industrial production growth, which increases the domestic and industrial waste.

Polymer packaging materials are one of the top among solid domestic waste. Every year about 158 million tones of polymer packaging material are produced in the world, only $20 \%$ out of this is recycled, all the rest, which is not disposed in the right way goes to the environment. That is why it is important to produce and use an alternative material that

*Correspondingauthor:joker775.87@mail.ru 
could be easily recycled and assimilated by soil microorganisms, which would be safe for the ecology.

There are two ways of polymer packaging material biodegradation: the first one is to fill the commercial packaging (polypropylene, polyethylene, polyethylene-terephthalate, etc) with the starch, which leads to polymer chain termination, and the second one is to use biodegradable polymers as packaging [1]. One of them is a polylactide (PLA) extracted from raw vegetable (corn, potato, sugarcane, manioc, rice, etc) which makes it a promising alternative to polymer produced from petroleum. Its stress-strain behavior matches those of traditionally used industrial polymers and it is able to be recycled by all plastics processing methods [2-4]. PLA is widely used in many industrial sectors. In packaging [5] polylactide is used in overwrapping films for the food, shrink packaging, disposable cutlery, food containers, teabags, bags, flower pots, phone cases, laptop cases [6] and other small appliances are made from polylactide. The polylactide strands are widely used for 3D printing as expendable supplies [7]. There have been developments of using PLA in the waste water purification [8]. Polymer is also actively used in the medicine thanks to its biodegradation and biocompatibility: bone implants [9] are produced from polymer, placeholder pins [10], plates [11], a grid [12] and suture material [13]. PLA products have an attractive appearance, transparency, high mechanical performance and good barrier properties.

One more tendency of packaging industry is the development of composite materials, which consist of thermoplastic polymers, wood powder, mineral and organic fillers and also finishing materials [14]. However, adding raw wood powder can lead to the fast product decomposition. The solution of this problem is a filler thermal modification, which can extend the product validity period by extracting hemicelluloses from the wood that reduces the product validity period $[15,16]$.

A principal objective of this paper is to review the assessment of the wood filled PLA and wood powder composite material stress-strain behavior and to determine the capability of using composites in packaging production.

\section{Materials and methods}

To analyze a stress-strain behavior of wood filled materials on Test Sample Injection Moulding Apparatus with the $200{ }^{\circ} \mathrm{C}$ temperature and 8 bar pressure, we have got 3 series of composite samples with a different component mass concentration and a preliminary filler thermal modification temperature and PLA samples. The composition formulation is shown in Table 1. We used the following samples: smooth strips with no cuts $80 \mathrm{~mm}$ length, $10 \mathrm{~mm}$ width and $4 \mathrm{~mm}$ thick without swelling, inequality, sheared surface and other visual defects.

Table 1. Composition formulation.

\begin{tabular}{|c|c|c|c|c|}
\hline \multirow{3}{*}{ Series } & $\begin{array}{c}\text { PLA (4043D, } \\
\text { NatureWorks), \% }\end{array}$ & $\begin{array}{c}\text { Wood powder } \\
(180, \text { pine), } \%\end{array}$ & $\begin{array}{c}\text { Preliminary filler thermal } \\
\text { modification } \\
\text { temperature, }{ }^{\circ} \mathrm{C}\end{array}$ & $\begin{array}{c}\text { Number of } \\
\text { samples }\end{array}$ \\
\hline \multirow{4}{*}{1} & 80 & 20 & 130 & 10 \\
\cline { 2 - 5 } & 70 & 30 & 130 & 10 \\
\cline { 2 - 5 } & 60 & 40 & 130 & 10 \\
\hline \multirow{3}{*}{2} & 40 & 50 & 130 & 10 \\
\cline { 2 - 5 } & 80 & 30 & 200 & 10 \\
\cline { 2 - 5 } & 70 & 40 & 200 & 10 \\
\hline
\end{tabular}




\begin{tabular}{|c|c|c|c|c|}
\hline & 40 & 50 & 200 & 10 \\
\hline \multirow{3}{*}{3} & 80 & 20 & 240 & 10 \\
\cline { 2 - 5 } & 70 & 30 & 240 & 10 \\
\cline { 2 - 5 } & 60 & 40 & 240 & 10 \\
\hline \multirow{3}{*}{4} & 40 & 50 & 240 & 10 \\
\hline
\end{tabular}

Impact strength test method, static bending elastic coefficient method and composite density method is shown in Table 2 .

Table 2. Experimental procedure.

\begin{tabular}{|c|c|c|}
\hline Characteristic & Reference document & Method \\
\hline Impact strength & $\begin{array}{c}\text { GOST 19109-2017 } \\
\text { Plastic. Izod impact strength } \\
\text { test method }\end{array}$ & $\begin{array}{c}\text { A cantilevered test sample is } \\
\text { smashed up by pendulum blow on } \\
\text { a certain distance of the fixed } \\
\text { point. }\end{array}$ \\
\hline Bending resistance & $\begin{array}{c}\text { GOST 4648-2014 } \\
\text { Plastic. Static bending test } \\
\text { method }\end{array}$ & $\begin{array}{c}\text { Test sample supported by piers is } \\
\text { bended with the constant speed in } \\
\text { the middle between its piers before } \\
\text { its destruction or before getting its } \\
\text { relative strain value. }\end{array}$ \\
\hline Density & $\begin{array}{c}\text { GOST R 57713-2017 } \\
\text { Polymer composites. } \\
\text { Density method and absolute } \\
\text { volume density rate }\end{array}$ & $\begin{array}{c}\text { Test sample is weighed in air and } \\
\text { water }\end{array}$ \\
\hline
\end{tabular}

To define the impact strength of composites we used the Charpy Impact machine GT7045-MDL with energy rate 5,5 $\mathrm{J}$, pendulum speed $3,46 \mathrm{~m} / \mathrm{s}$ and incidence angle $150^{\circ}$.

Binding resistance test was carried out by the multipurpose tensile testing machine ZwickZ010. The testing rate was $2 \mathrm{~mm} / \mathrm{min}$.

The density of composites was measured by BM-22 Micro Balance.

\section{Results and discussion}

Equations should be centred and should be numbered with the number on the right-hand side.

Table 3. The results of impact strength test of wood filled composites without cuts by normal temperature $\left(22^{\circ} \mathrm{C}\right)$.

\begin{tabular}{|c|c|c|c|}
\hline \multirow{2}{*}{ Series } & $\begin{array}{c}\text { PLA/filler, \% - treatment } \\
\text { temperature, }{ }^{\circ} \mathrm{C}\end{array}$ & $\begin{array}{c}\text { Impact power } \\
A_{n}, \mathrm{~J}\end{array}$ & $\begin{array}{c}\text { Sample impact strength } \\
a_{n}, \mathrm{~kJ} / \mathrm{m}^{2}\end{array}$ \\
\hline \multirow{4}{*}{1} & $80 / 20-130$ & 0,5159 & 12,898 \\
\cline { 2 - 4 } & $70 / 30-130$ & 0,4371 & 10,928 \\
\cline { 2 - 4 } & $60 / 40-130$ & 0,3559 & 8,898 \\
\cline { 2 - 4 } & $50 / 50-130$ & 0,2936 & 7,34 \\
\hline \multirow{4}{*}{2} & $80 / 20-200$ & 0,4943 & 12,358 \\
\cline { 2 - 4 } & $70 / 30-200$ & 0,4076 & 10,19 \\
\cline { 2 - 4 } & $60 / 40-200$ & 0,3294 & 8,235 \\
\hline \multirow{3}{*}{3} & $50 / 50-200$ & 0,2319 & 5,798 \\
\cline { 2 - 4 } & $80 / 20-240$ & 0,4625 & 11,563 \\
\hline
\end{tabular}




\begin{tabular}{|c|c|c|c|}
\hline & $60 / 40-240$ & 0,2841 & 7,103 \\
\cline { 2 - 4 } & $50 / 50-240$ & 0,1884 & 4,71 \\
\hline
\end{tabular}
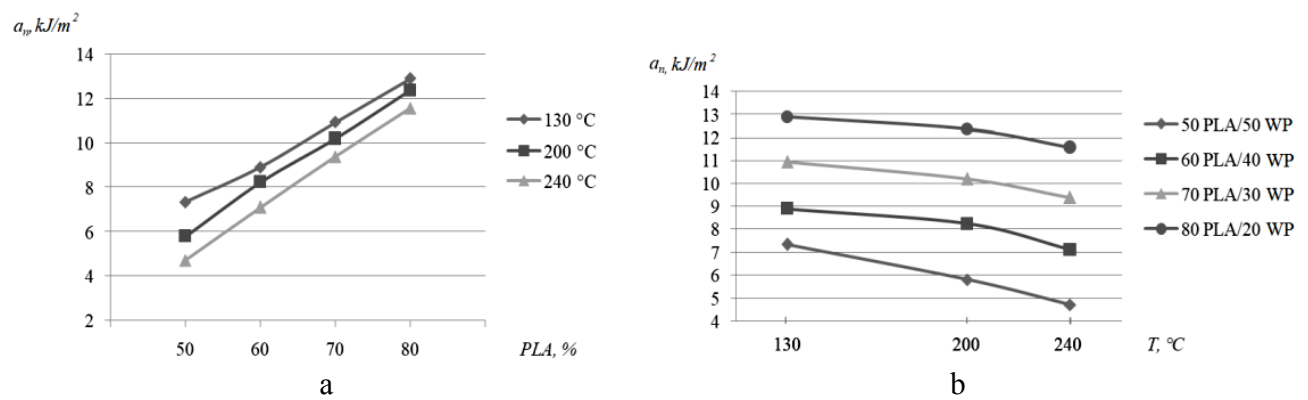

Fig. 1. a - PLA concentration and filler preliminary thermal treatment temperature influence on the bending elastic coefficient; $b$ - dependence of bending resistance on the filler preliminary thermal treatment temperature.

In accordance with the results (fig. 1), by decreasing the amount of filler, the impact strength of the composite is increasing, however this value of PLA samples was $13,5 \mathrm{~kJ} / \mathrm{m}^{2}$. At the same time, the samples containing the wood powder dried by $130^{\circ} \mathrm{C}$ have higher impact strength than those with the wood powder that was preliminary thermally modified by $200{ }^{\circ} \mathrm{C}$ and $240{ }^{\circ} \mathrm{C}$. Relatively low impact strength of samples with thermally modified filler shows the high fragility of composites.

Table 4. The wood filled composites static bending test results by normal $\left(22^{\circ} \mathrm{C}\right)$ temperature.

\begin{tabular}{|c|c|c|}
\hline \multirow{3}{*}{ Series } & $\begin{array}{c}\text { PLA/filler, } \%-\text { treatment } \\
\text { temperature, }{ }^{\circ} \mathrm{C}\end{array}$ & $\begin{array}{c}\text { Bending elastic coefficient } \\
E_{f}, \mathrm{MPa}\end{array}$ \\
\hline \multirow{4}{*}{1} & $80 / 20-130$ & 0,5159 \\
\cline { 2 - 3 } & $70 / 30-130$ & 0,4371 \\
\cline { 2 - 3 } & $60 / 40-130$ & 0,3559 \\
\cline { 2 - 3 } & $50 / 50-130$ & 0,2936 \\
\hline \multirow{4}{*}{2} & $80 / 20-200$ & 0,4943 \\
\cline { 2 - 3 } & $70 / 30-200$ & 0,4076 \\
\cline { 2 - 3 } & $60 / 40-200$ & 0,3294 \\
\hline \multirow{5}{*}{3} & $50 / 50-200$ & 0,2319 \\
\cline { 2 - 3 } & $80 / 20-240$ & 0,4625 \\
\cline { 2 - 3 } & $70 / 30-240$ & 0,3754 \\
\cline { 2 - 3 } & $60 / 40-240$ & 0,2841 \\
\hline
\end{tabular}
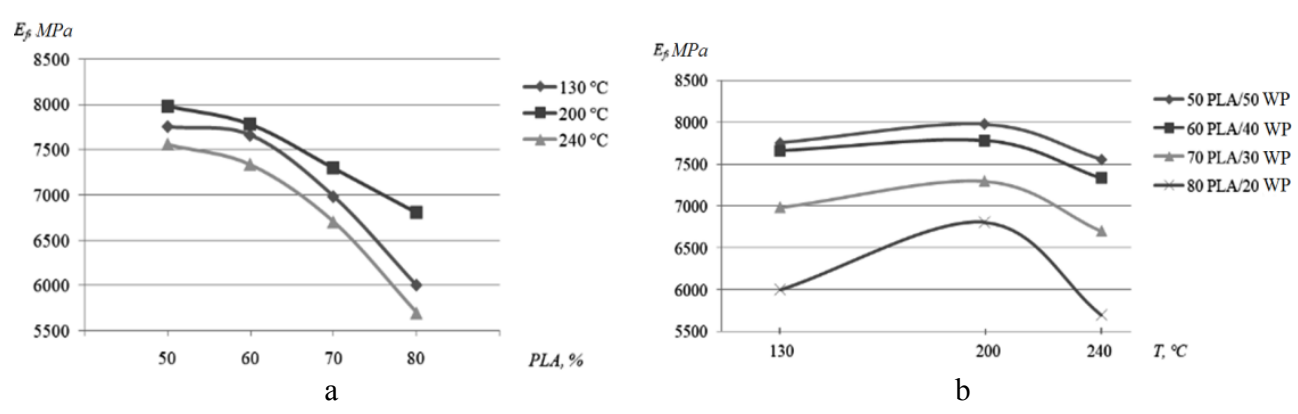
Fig. 2. a - PLA concentration and filler preliminary thermal treatment temperature influence on the bending elastic coefficient; $b$ - dependence of bending resistance on the filler preliminary thermal treatment temperature.

As Figure 2 shows, with PLA decrease the static bending elastic coefficient is increasing. However, the samples containing the wood powder dried by $130^{\circ} \mathrm{C}$ and preliminary thermally modified by $200{ }^{\circ} \mathrm{C}$ have the elastic coefficient increase, and those samples with the wood powder thermally modified by $240{ }^{\circ} \mathrm{C}$ have the elastic coefficient decrease due to a molecular scale change in the wood. PLA sample elastic coefficient was $2300 \mathrm{MPa}$.

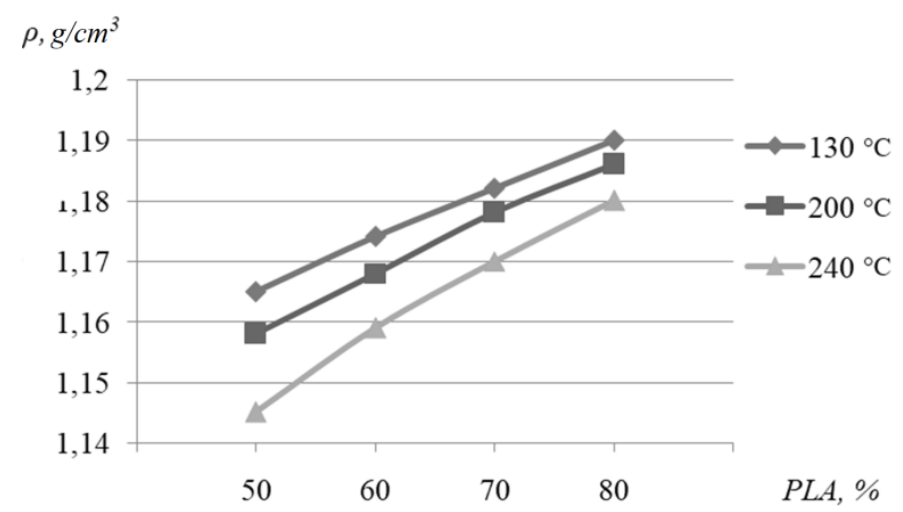

Fig. 3. PLA concentration and filler preliminary thermal treatment temperature influence on density.

\section{Conclusion}

The results of the research show the following:

1) with the increase of the amount of filler concentration and its heating temperature the impact strength of the composites decreases which shows the high fragility of the composites.

2) with the increase of the amount of filler concentration the static bending of elastic coefficient increases. While adding the wood powder heated by $130{ }^{\circ} \mathrm{C}$ and $200{ }^{\circ} \mathrm{C}$ the elastic coefficient increases, while adding the wood powder heated by $240{ }^{\circ} \mathrm{C}$ the elastic coefficient decreases.

3) with the increase of filler concentration and its heating temperature, the composite density decreases.

4) the wood filler concentration of $40 \%$ heated by $200{ }^{\circ} \mathrm{C}$ is enough to keep a relatively high stress-strain behavior of composites. With the higher amount of wood filler it is possible to reduce production costs, but the product quality of this material will significantly go down. However, depending on application target and life cycle of this product, it is possible to develop the formulation that will have a higher filler concentration.

This work was performed with support of grant of the President of the Russian Federation for state support of young Russian scientists - PhD (MK-2246.2020.8)

\section{References}

1. N. Ayrilmis, S. Jarusombuti, V. Fueangvivat, Effect of thermal-treatment of wood fidres on properties of flat-pressed wood plastic composites, Polymer Degradation and Stability, 96, 818-822 (2011). 
2. C. M. Chan, L.-J.Vandi, S. Pratt, P. Halley, D. Richardson, A. Werker, B. Laycock Composites of Wood and Biodegradable Thermoplastics: A Review, Polymer Reviews, 58, 444-494 (2018)

3. R.R. Safin, I.F. Khakimzyanov, N.R. Galyavetdinov, S.R. Mukhametzyanov, Gasification of torrefied fuel at power generation for decentralized consumers, IOP Conference Series: Earth and Environmental Science, 87/3, 032035 (2017)

4. G. Reddy, M. Altaf, B.J. Naveena, M. Venkateshwar, E.V. Kumar, Amylolytic bacterial lactic acid fermentation - A review, Biotechnology Advances, 26, 22-34 (2008)

5. S. Obuchi, S. Ogawa, Packaging and other commercial applications, Poly(Lactic Acid): Synthesis, Structures, Properties, Processing and Applications, 457-467 (2010)

6. H. Tsuji, Degradation of Poly (Lactide)-Based Biodegradable Materials, New York: Nova Science Pub Inc., 76-78 (2008)

7. G.A. Sabirova, R.R. Safin, N.R. Galyavetdinov, A.R. Shaikhutdinova Research of biodegradable wood completed composite materials based on polylactide, Journal of Physics: Conference Series Krasnoyarsk Science and Technology City Hall of the Russian Union of Scientific and Engineering Associations, 44117 (2019)

8. A. Hiraishi, Environmental Applications, Poly(Lactic Acid): Synthesis, Structures, Properties, Processing and Applications, 457-467 (2010)

9. M.J. Yaszemski, R.G. Payne, W.C. Hayes, R. Langer, A.G. Mikos, Evolution of bone transplantation: molecular, cellular and tissue strategies to engineer human bone, Biomaterials, 17, 268-275. (1996)

10. H. Pihlajamaki, O. Bostman, O. Tynninen, O. Laitnen, Long-term tissue response to bioabsorbable pole-l-lactide and metallic screws: An experimental study, Bone, 39, 932-937 (2006)

11. T. Suzuki, H. Kawamura, T. Kasahara, H. Nagasaka, Resorbable poly-l-lactide plates and screws for the treatment of mandibular condylar process fractures: a clinical and radiologic follow-up study, Journal of Oral and Maxillofacial Surgery, 62, 919-924 (2004)

12. R. De Tayrac, S. Chentouf, H. Garreau, C. Braud, I. Guiraud, P. Boudeville, M. Vert, In vitro degradation and in vivo biocompatibility of poly(lactic acid) mesh for soft tissue reinforcement in vaginal surgery, Journal of Biomedical Materials Research Part B: Applied Biomaterials, 85B, 526-539 (2008)

13. S.Suzuki, Y. Ikada, Medical Applications, Poly(Lactic Acid): Synthesis, Structures, Properties, Processing and Applications, 445-456 (2010)

14. R.R. Safin, N.R. Galyavetdinov, S.R. Mukhametzyanov, A.R. Shaikhutdinova, R.R. Khasanshin, Technology for producing high-quality natural biodegradable plastic for $3 D$ printer, International Multidisciplinary Scientific GeoConference Surveying Geology and Mining Ecology Management, SGEM, 19/4.1, 503-509 (2019)

15. R.R. Safin, G.A. Talipova, N.R. Galyavetdinov, Design of packaging materials based on polylactide and wood filler, International Journal of Engineering and Technology(UAE), 4.36, 1089-1091 (2018)

16. R.R. Safin, G.A. Talipova, N.R. Galyavetdinov, F.V. Nazipova, R.V. Salimgaraeva, The study of the destructive properties of wood-filled composites for the production of biodegradable packaging materials, International Multidisciplinary Scientific Geoconference, 19, 541-546 (2019) 